\title{
PROBLEMS OF TRANSLATION OF PROVISIONS OF INTERNATIONAL TREATIES ILLUSTRATED BY THE EXAMPLE OF ARTICLE 6 OF THE EUROPEAN CONVENTION FOR PROTECTION OF HUMAN RIGHTS AND FUNDAMENTAL FREEDOMS
}

\begin{abstract}
The subject of these reflections is the analysis of issues concerning language translation of the treaty and connotations connected therewith of the meaning of legal regulations. As an example here one can cite Article 6 of the European Convention for the Protection of Human Rights and Fundamental Freedoms of 1950, prepared in the two official languages of the Council of Europe, i.e. English and French. The problems of interpretation of Article 6, which regulates the right to a fair trial, resulted from the official translation of the term "prawo do sprawiedliwego procesu sacdowego" (the right to a just trial). This triggered a quite widespread discussion in the Polish doctrine as to whether the English term "fair" should be translated as "sprawiedliwy". Moreover, on the basis of a translation so constructed other proposals of the concept in Article 6 appeared in the literature on the subject, such as "uczciwy" (honest), "słuszny" (right) or "praworzadny" (lawful) trial. The article presents the argumentation of Polish lawyers on adopting the aforementioned terms, demonstrating how the language used in translation of the treaty may affect the accurate understanding of legal terminology.
\end{abstract}

Keywords: fair trial, human rights, translation of treaties

\section{Introduction}

A key to understanding international treaties and their proper application is correct reading of the interpretation methodology used in their translation (Mik, 1992: 11, Ehrlich, 1957, Czapliński, Wyrozumska, 1999: 358-362, Watts, 1996: 1269-1280. In accordance with fundamental arrangements of the theory of law, in the process of law application one may distinguish types of reasoning and argumentation concerning validation arrangements (normative basis of the decision), interpretative arrangements (interpretation of a legal norm), establishment of the actual state of affairs, 


\section{Iwona Wrońska}

subsumptive arrangements (juxtaposition of the determined actual state of affairs with the legal norm derived from interpretation), a selection of legal consequences (legal sanction) as well as the rationalization of a decision and how it was arrived at (justifying the decision) (Wróblewski, 1988: 93-95).

By and large it can be asserted that in the interpretation of provisions of international law as well as national law, the same rules of interpretation are applied. The procedures of derivative interpretation (reconstruction of a legal norm) and clarification interpretation (determination of meanings of normative expressions) are the same. However, in particular types of interpretation specific proportions as well as relations between the rules of interpretation are altered (Wróblewski, 1988: 93-95). The fundamental distinctness concerning interpretation of provisions of international agreements is connected with the presence of a clear international normative regulation, determining the way of interpretation of international agreements, i.e. Articles 31-33 of the Vienna Convention on the Law of Treaties of 28 May 1969 (hereinafter: VCLT) (Dz.U. 1990, no. 74, item 439). These rules are of general nature and mainly refer to classical international treaties or treaties which serve to execute rights and responsibilities of states-parties, operate in mutual relations, thus on the horizontal plane (compare Article 3, Articles 34-38 + of VCLT) (Mik, 1992: 11), whereas treaties on the protection of human rights are of no typical nature; they appertain to the constantly growing group of treaties operating in the sphere of vertical relations, typically: entities under state jurisdiction - state authorities (Mik, 1992: 11). This results in the situation where, beside classical directives of interpretation, appear specific directives of interpretation and the so-called functional rules of interpretation (Mik, 1994: 11-15).

The subject of these reflections is the analysis of one example which demonstrates when and to what extent the interpretation of a treaty is impeded due to the questions of language translation. This paper discusses the issue of formal official translation of Article 6, ECHR, i.e. the right to a fair trial, from the English language into the Polish language, and numerous interpretative connotations connected therewith which subsequently appeared in the Polish legal doctrine. Analysis of the argument embraces the disputable term in the language translation of Article 6 as a "just" trial, not "fair" trial (which is understood as reliable by Polish representatives of the doctrine). Simultaneously, the article omits the question of the provisions of Article 6 , which, as a collection of trial guarantees, did not cause interpretative doubts in the context of language translation.

One of the most significant international agreements including the protection of human rights in the scope of the right to a fair trial in the Pol- 
ish legal system, is the European Convention for the Protection of Human Rights and Fundamental Freedoms of 1950 (herein: ECHR or European Convention), signed by member states of the Council of Europe. The treaties on human rights protection, like other international agreements, are usually written in two or even more authentic languages. The European Convention has two official languages: English and French, in accordance with the rule provided in the Statute of the Council of Europe which states that the official languages of this organization are English and French. It is undeniable that wordings and terms used in these texts are derived from traditional English and French terminology (Hofmański, 1995: 127). The problem is that they are mutually very distant and often use different terms to define the same notions or the same terms to define various subject-matter (Hofmański, 1995: 127). Thus, analysis of the interpreted provision of ECHR sometimes forces the reader to analyze both official texts and, as often occurs, to also delve into problems manifested in the English and French legal systems.

The existence of two official languages in ECHR necessitates interpretation aimed at coordinating the meanings of particular expressions in different languages and, in cases where this is impossible, selecting the one which best serves to secure realization of the subject and objective of the treaty, in circumstances of the fullest possible coordination of different texts (Mik, 1992: 16). This type of procedure is visible in the context of interpretation and translation of the term fair trial, or the right to a fair trial provided in Article 6 where in the English version it is expressed as following:

\section{Art. 6 Right to a fair trial}

1. In the determination of his civil rights and obligations or of any criminal charge against him, everyone is entitled to a fair and public hearing within a reasonable time by an independent and impartial tribunal established by law. Judgment shall be pronounced publicly but the press and public may be excluded from all or part of the trial in the interests of morals, public order or national security in a democratic society, where the interests of juveniles or the protection of the private life of the parties so require, or to the extent strictly necessary in the opinion of the court in special circumstances where publicity would prejudice the interests of justice (...).

In the official Polish language version of ECHR announced in Dziennik Ustaw (Journal of Laws), Article 6 was translated as the right to a fair trial:

1. Każdy ma prawo do sprawiedliwego $i$ publicznego rozpatrzenia jego sprawy w rozsadnym terminie przez niezawisty $i$ bezstronny sad ustanowiony ustawa przy rozstrzyganiu o jego prawach $i$ obowiazkach o charakterze cy- 
wilnym albo o zasadności każdego oskarżenia w wytoczonej przeciwko niemu sprawie karnej. Postępowanie przed sadem jest jawne, jednak prasa i publiczność moga być wyłaczone z całości lub części rozprawy sądowej ze względów obyczajowych, z uwagi na porzadek publiczny lub bezpieczeństwo państwowe w spoteczeństwie demokratycznym, gdy wymaga tego dobro mało-

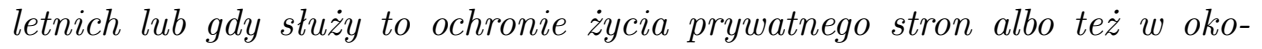
licznościach szczególnych, w granicach uznanych przez sad za bezwzględnie konieczne, kiedy jawność mogłaby przynieść szkodę interesom wymiaru sprawiedliwości (...).

\section{The main arguments}

While the dissimilarities of the language translation of Article 6 presented above appear to be dogmatic, in reality they represent an important dimension and, according to certain representatives of the doctrine, represent concrete legal effects especially in the sphere of trial procedure. It should be emphasized that doctrinal considerations in Poland on the translation of Article 6, have been based mainly on the the English version of ECHR and therefore this analysis is limited to the English text. The different translation of Article 6 into Polish as regards the terminology of the specificity of court trial, initiated quite a large doctrinal discussion: if and to what extent exists a difference in the interpretation of a trial, as "fair" (reliable), in the English version of ECHR and, respectively, as "just" in the Polish version of the treaty. Does such a language translation affect the understanding of the catalogue of guarantees provided by Article 6 and generally a trial before a court in a democratic state in accordance with the standards of the Council of Europe?

In the Polish legal literature the most frequently occurring concepts determining the character and specificity of a court trial are: "the right to a judicial way (prawo do drogi sądowej)" (Wróbel, 1991: 40), "the right to a lawful (prawo do praworządnego procesu sądowego) trial" (Michalska, 1982: 152, Wędrychowski, 1991: 62), "the right to an honest (prawo do uczciwego procesu sądowego) trial” (Szafarz, 1997: 8, Waltoś, 1996: 303, Cieślak, 1984: 367), "the right to an honest hearing" (Michalska, 1982: 152, Wędrychowski, 1991: 62), "the right to a reliable (prawo do rzetelnego procesu sądowego) trial before a court of law" (Nowicki, 1992: 52), "the right to an honest/reliable judicial proceedings (prawo do rzetelnego procesu sądowego)", "the right to a lawful trial/hearing" (Kubicki, 1971: 927), "the right to a just (prawo do sprawiedliwego procesu sądowego) trial" 
(Kmieciak, 1996: 3, Zieliński, 1992: 15) or a term, used by Jasudowicz, "the right to a right (prawo do słusznego procesu sądowego) trial". It is important to note the semantic hue of the adjectives used here: "praworzacdny" (lawful), "sprawiedliwy" (just), "rzetelny" (reliable), and "uczciwy" (honest) are not homogeneous. Certain authors use the terms which result from ratified international agreements guaranteeing the right to fair (reliable) judicial proceedings (Nowicki, 1992: 52; Wędrychowski, 1991: 62). Other authors build the name of the judicial trial as a standard proper for democratic states on the basis of legal traditions, legal regulations and axiological justification referring to human rights.

The variety of terms results from different rules of the interpretation of the citizen's powers, which consists in the right to search for legal protection before an independent and impartial judicial body. For if the theoreticians of law associate the right to justice (trial before a court of law) mainly with the access to the court of law, the right to trial (fair/reliable, just, honest etc.) directs our attention to procedural guarantees in the course of the proceedings in progress, i.e. lawful, open/transparent and just recognition of the case respecting elementary legal procedural standards. The fact that the European Convention was prepared in two equally authentic texts, English and French , means that in accordance with the interpretation rules of the norms of international law, it is necessary to apply such an interpretation that allows for coordination of the meanings of the expressions appearing in the two different languages (Mik, 1994: 228).

Thus, it is worth looking into the varied understanding of ideas and specificity of a trial before a court of law in the context of Article 6 in the Polish legal literature. The analysis begins with the official Polish translation of Article 6, i.e. "sprawiedliwy proces sądowy" (just trial before a court of law).

Taking into consideration the purpose of a trial (both civil and criminal) before a court of law, which is reaching the state of legal substantive justice and procedural justice, the literature notes that the application of the term "just" is a well-grounded practice in the context of defining purposes of judicial proceedings. Just procedure is discussed by Daszkiewicz, who claims that just procedure is the procedure which secures compliance of judgments with the norms of substantive law (Daszkiewicz, 1994: 44). This results from the exposition of the ancillary role of a criminal trial in relation to a superior purpose, which is the implementation of the norms of substantive criminal law. Krzyżanowska-Mierzejewska refutes this interpretation of Article 6, pointing to the fact that this translation emphasizes the outcome of the procedure, which should be "just" (Krzyżanowska-Mierzejewska, 2003: 38- 
39). Of course this may just be a question of language convention but it does seem that a more correct translation would be "prawo do rzetelnego procesu" ("fair trial" meaning "reliable" and "honest"), which would emphasize the procedural aspect of the judicial proceedings, their procedural elegance and guarantee of equal rights of both parties, and not their result. An infringement of human rights, according to Article 6, is a trial conducted fairly (reliably), the result of which the complainant disagrees with rather than a trial conducted unfairly (unreliably), the result of which is accepted by the complainant. Defining Article 6 of ECHR as "the right to a just (sprawiedliwego) trial", results, according to Krzyżanowska-Mierzejewska, from a common understanding of justice, which attaches importance to the result of the proceedings exclusively, completely dismissing their procedural aspects (it is the so-called distributive justice, justice of the result, understood as serving individual interests based on merit with procedural justice often being overridden) (Krzyżanowska-Mierzejewska, 2003: 38-39).

Hofmański also holds a similar position, asserting that the official version of the translation, adopted in the Dziennik Ustaw (Journal of Laws), defining a trial as "just" is improper. In his opinion, the term "just" (sprawiedliwy) "seems to more relativize to the result of the proceedings (judgment) than the proceedings themselves and their course, which is the balance point of the whole structure of Article 6 of the European Convention" (Hofmański, 1997: 92-93). Moreover, Hofmański observes that referencing the term "fair trial" to the term "just trial" (sprawiedliwy process) is also erroneous due to the fact that the latter does not address the rules of proceedings but rather their effect (Hofmański, 1997: 92-93, Directorate of Human Rights, 1998: 64-70). Therefore, it is more correct to use the expression "rzetelny process sądowy" ("fair trial" where fair = reliable/honest). It is also important to note that it is the English version of ECHR that is fundamental in understanding the expression, where the expression fair hearing is present, whereas the French version, droit à ce quo sa cause soit entendue équitablement, is semantically derived from the English expression; therefore, it is possible and necessary to discern the occurrence on the part of a human individual a "claim" but a claim for fair (reliable) proceedings (Hofmański, 1995: 237).

Mik in keeping with Hofmański, denies the accuracy of the translation of ECHR in the Dziennik Ustaw RP (Journal of Law of the Republic of Poland), where "fair" is translated as "sprawiedliwy" (just). However, he opts for the translation of this term as "słuszny" (right). He maintains that the use of the term "just" is not a fundamental mistake. Nevertheless, it does not reveal the real substance of the provision of Article 6, because 
the attribute of justice in international law is of general character, whereas rightness (słuszność) is the application of justice for a particular case, which means for the particular circumstances of the case (Mik, 1996: 63).

The doctrine of law also contains a definition of guarantees resulting from Article 6 as "prawo do słusznego procesu sądowego" (the right to a right/equitable trial before the court) (Jasudowicz, 1998: 213; Gronowska, 1996: 141). Dictionaries, under the entry "słuszność" (rightness/equity), refer to the concept of justice or an obligation of not doing wrong to others (Pradel, 1996: 7). For Littré, stuszność (rightness/equity) is "readiness to allot everyone an equal part, to impartial recognition of the right of each person" (Littré, 1966). Bearing in mind such definitions of rightness, certain theoreticians of law attribute the abovementioned qualities to judicial proceedings. On the basis of the whole text of Article 6, two definitions of rightness/equity (słuszność) may be taken into consideration. In the strict sense of the word, rightness/equity (słuszność) "assumes that each of the parties in litigation may defend their case (...) in such a way that in the course of the whole trial, was not in a situation essentially less favorable than the opposite party". The word 'equity' (équité) comes from the Latin aequus and means equal, balanced (Pradel, 1996: 8). This term, thus, contains respect for the right to defense, equality of arms, necessity of adversarial procedure etc. (Pradel, 1996: 8).

Another definition of the regulation of Article 6 of the European Convention which occurs in the literature on the subject is "honest judicial proceedings" (uczciwe postępowanie sądowe). Wędrychowski uses it, highlighting that the term "honest hearing" is the best rendition of the sense of all regulations of Article 6 because it refers foremost to human rights which should be respected in the course of the trial before the court (Wędrychowski, 1991: 64). According to some scholars, "an honest trial" means a trial conducted in accordance with the rules of criminal procedure protecting individual rights (Wędrychowska and Wędrychowski, 1997: 247). It should be a synthesis of the fundamental principles of the modern criminal trial ((Wędrychowska and Wędrychowski, 1997: 247). Critics of the definition of a trial as "uczciwy" (honest) claim on the basis of Article 6 that this expression seems to be too subjective and refers foremostly to the moral values of judicial bodies (judges), and less to the normative sphere (Hofmański, 1995: 238). Waltoś holds a similar position, underscoring that the concept of honest trial refers mainly to moral norms (Waltoś, 1996: 303). Cieślak is of a similar opinion, emphasizing the fact that an honest trial is a trial where the system of moral values accepted by society has not been infringed (Cieślak, 1984: 367), whereby, as Hofmański also observes, the 
concept of honest trial is too subjective (Hofmański, 1995: 238, Hofmański, 1997: 92-93, Directorate of Human Rights, 1998: 64-75).

Barącz (1991:74-75) also disagrees with the concept of honest trial adopted to define a set of legal guarantees included in Article 6 of ECHR: "Honesty of a trial should not be identified with the notion fair trial. The European Convention regulates the model of trial before the court of law, ordering the states-parties placing a certain minimum of trial guarantees in their internal legislations, whereas the proposed concept of honesty means assessment of a particular trial not only from the legal point of view, because by all means in the common understanding the simple consistency of the proceedings with the valid positive law does not decide on its honesty. This issue is situated at the borderline of law, ethics and morality, and a trial is assessed as honest or dishonest as if from outside of the system of law". The way of understanding honesty must, thus, refer to extra-normative criteria, not excluding pure intuition concerning rightness. In addition, Barącz (1991) underscores that many different components of criminal procedure or phenomena connected therewith may, by nature, be subject to ethical evaluation. It may be either the way of conducting a particular trial, or the rightness of the norms making the binding model of proceedings, as well as norms of substantive law on the basis of which the trial is conducted, and, finally, personal honesty and fairness of the judge. Procedural law or its particular provisions may be wrong, unjust, harming and, finally, may infringe certain individual rights. However, it is generally difficult to classify such shortcomings as dishonest (Barącz, 1991: 74-75).

The examples of attributes of a trial discussed above contain expressions which are certainly more about naming some of its elements than a satisfying explanation of the essence of the concept of the right to a trial. However, they are both relevant and optimal terms, because they illustrate the problems marked within them. The concept of right to a trial has a certain structure of legal guarantees, which with other planes of functioning of a democratic state constitutes a certain order, and the theoretical number of legal categories (sprawiedliwy/just, słuszny/right, uczciwy/honest or rzetelny/fair/reliable trial), with which one may determine the right to a trial, is extensive in the Polish literature. The structure in the scope of interpretation of Article 6 is referred foremost to the sphere of constitutional principles in force in the judicial system of a democratic state. This point of reference seems correct.

Summing up, bearing in mind the numerous positions of the representatives of legal doctrine on attributes of the regulation in Article 6 of ECHR, it is possible to observe that the question of language translation of an in- 
ternational agreement in practice may raise several problems. In concluding reflections on the interpretation of Article 6 concerning the terminology of the right to a trial, it is important to state that all are terms expressing the same substance, even though, which is obvious, emphasizing different specific elements. In Polish legal literature, however, and despite a different official translation, the terms whih dominate when referring to the concept of "fair (reliable) hearing" (rzetelna rozprawa) (Hofmański, 1998: 36) are: "fair (reliable) trial before the court" (rzetelny process sacdowy), which is used by numerous scholars (Nowicki, 1999a: 134; Nowicki, 1999b: 107; Wiliński, 2003: 164-165; Hołda et al. 2004: 124; Nowak, 1999: 38; and "fair (reliable) proceedings" (rzetelne postępowanie) (Hofmański, 1995: 237-238, Hofmański, 1993: 16, Redelbach, 1997: 13, Redelbach, 2001: 284-286. These terms are widely adopted in practice and should be recognized as being closest to the essence of the English fair trial established by Article 6. The guarantees defined as the right to a fair (reliable) trial mean securing a reliable/honest judicial procedure, i.e.: honesty, justice, rightness/equity and the principles of a democratic state of justice (Rechtsstaat). It seems that the sum of these notions results in the image of judicial proceedings determined by ECHR. Consideration as to which term should be recognized as superior and binding seems not to be of significant importance in the judicial practice of national courts and does not raise fundamental controversies (Judgement, 1992). The right to a fair trial is by all means the legal imperative which should be foremost interpreted in a subjective and objective way within the range of the guarantees included therein, and the concept terms defining the right to a trial are a lesser problem, which, in the practice of state bodies has no effect on its essence.

\section{Conclusions}

The different terms defining the set of guarantees included in Article 6 of ECHR present in the Polish doctrine, result from the lack of appropriate internal legislation in 1993, when Poland ratified ECHR, which would normatively determine the rules of the official translation of international agreements to which Poland is a party. It is worth underscoring that currently the Polish legal order contains an act on international agreements and implementing regulations on applying certain provisions of the law on international agreements, which determine the rules of concluding international treaties by Poland - Act of 14 April 2000 on International Agreements and Regulation of the Council of Ministers of 28 July 2000 on application of 
certain provisions of the Act on the International Agreements (Act, 2000, Regulations 2000). What deserves special attention is the aforementioned implementing regulation, which requires that the conclusions on all stages of the procedure of concluding the agreements are attached with translations into Polish of the agreement and any reservations, objections and declarations referring thereto (in cases where the language of agreements is not Polish), are endorsed by a competent minister (who thereby is responsible for the quality of the translation). This certainly facilitates the interpretation of international agreements and, as a rule, should eliminate basic doubts referring to the interpretation and application of the provisions of an international treaty.

\section{R E F E R E N C E S}

Act of 14 April 2000 on International Agreements, Dz. U. no. 39, item 443 as amended.

Barącz, M. 1991. 'Pojęcie i cechy „uczciwego procesu karnego'. Państwo i Prawo, 12: $74-75$.

Cieślak, M. 1984. Polska procedura karna. Podstawowe założenia teoretyczne. Warszawa: PWN.

Council of Europe. 1998. 'Article 6 of the European Convention on Human Right. The right to fair trial'. Human Rights, 3: Strasbourg: Council of Europe.

Czapliński, W. and A. Wyrozumska, 1999. Prawo międzynarodowe publiczne. Zagadnienia systemowe. Warszawa: C.H. Beck.

Daszkiewicz, W. 1994. Proces karny. Część ogólna. Warszawa - Poznań: Ars Boni et Aequi.

Directorate of Human Rights. 1998. Key extracts from a selection of judgements of the European Court of Human Rights and decision and reports of the European Commission of Human Rights. Strasbourg: Council of Europe.

Ehrlich, L. 1957. Interpretacja traktatów. Wyd. 1. Warszawa: Wydawnictwo Prawnicze PWN.

Frankowska, M. 1997. Prawo traktatów. Warszawa: Oficyna Wydawnicza Szkoły Głównej Handlowej.

Gronowska, B. 1996. 'Prawo do korzystania z pomocy obrońcy w postępowaniu apelacyjnym - sprawa Maxwella przeciwko Wielkiej Brytanii (Decision of 28 October 1993)'. Toruński Rocznik Praw Człowieka i Pokoju, 3: 141.

Hofmański, P. 1993. Prawa człowieka przed Trybunałem w Strasbourgu. Białystok: Wyd. Temida 2.

Hofmański, P. 1995. Konwencja europejska a prawo karne. Toruń: Wyd. TNOiK. 
Hofmański, P. 1997. Komentarz do wybranych przepisów Europejskiej Konwencji o ochronie praw człowieka i podstawowych wolności, in Hofmański (ed.) Standardy prawne Rady Europy. Teksty i komentarze, t. III, Prawo karne, 92-93. Warszawa: C.H. Beck.

Hofmański, P. 1998. Świadek anonimowy w procesie karnym. Kraków: Wyd. Zakamycze.

Hołda, J., Hołda, Z., Rybczyńska, J.A. and Ostrowska, D. 2004. Prawa człowieka. Zarys wykładu. Kraków: Wyd. Zakamycze.

Jasudowicz, T. 1998. Orzecznictwo strasburskie. Zbiór orzeczeń Europejskiego Trybunału Praw Człowieka 1990-1997, t. I. Toruń: Dom Organizatora.

Judgment of the Constitutional Tribunal, 7 January 1992, K8/91, OTK 1992.

Kmieciak, Z. 1996. 'Prawo do sprawiedliwego procesu sądowego a standardy sądowej kontroli administracji określone przez ustawę o Naczelnym Sądzie Administracyjnym'. Samorzad Terytorialny, 7:8, 3.

Krzyżanowska-Mierzejewska, M. 2003. 'Europejska Konwencja Praw Człowieka: Refleksja nad recepcją Konwencji w Polsce po dziesięciu latach od ratyfikacji'. Biuletyn Rady Europy, 3: 38-39.

Kubicki, L. 1971. 'Prawo karne europejskie (narodziny pojęcia)'. Państwo i Prawo, 12: 927.

Littré, E. 1966. Dictionnaire de la langue francaise, $V^{\circ}$ Equite. Gallimard - Hachette.

Michalska, A. 1982. Prawa człowieka w systemie norm międzynarodowych. Warszawa-Poznań: PWN.

Mik, C. (1992). 'Metodologia interpretacji traktatów z dziedziny ochrony praw człowieka'. Toruński Rocznik Praw Człowieka i Pokoju, 1: 11.

Mik, C. 1994. Koncepcja normatywna prawa europejskiego praw człowieka. Toruń: Wyd. UMK.

Mik, C. 1996. 'Prawo do procesu w sprawach cywilnych w orzecznictwie Europejskiego Trybunału Praw Człowieka lat 90'. Toruński Rocznik Praw Człowieka i Pokoju, 3: 63 .

Nowak, C. 1999. 'Zasada równości broni w europejskim i polskim postępowaniu karnym'. Państwo i Prawo, 3: 38.

Nowicki, M.A. 1992. Wokół Konwencji Europejskiej. Warszawa: Chotomów: Verba.

Nowicki, M.A. 1999a. Europejska Konwencja Praw Człowieka: wybór orzecznictwa. Warszawa: C.H. Beck.

Nowicki, M.A. 1999b. 'Z orzecznictwa Europejskiego Trybunału Praw Człowieka'. Palestra, 9-11: 107.

Płachta, M., A. and A. Wyrozumska. 2003. 'Interpretacja, obowiązywanie i skuteczność umów międzynarodowych w prawie polskim. Uwagi na tle uchwały Sądu Najwyższego z 19 lutego 2003 I KZP 47/02'. Państwo i Prawo, 6: 54.

Pradel, J. 1996. 'Rzetelny proces w europejskim prawie karnym'. Państwo i Prawo, 9: 7 . 


\section{Iwona Wrońska}

Redelbach, A. 1997. 'Zasada rzetelności postępowania w rozstrzygnięciach organów strasburskich'. Ruch Prawniczy, Ekonomiczny i Socjologiczny, 2: 13.

Redelbach, A. 2001. Natura praw człowieka, strasburskie standardy ich ochrony. Toruń: Towarzystwo Naukowe Organizacji i Kierownictwa "Dom Organizatora".

Regulation of the Council of Ministers of 28 July 2000 on execution of certain provisions of the Act on International Agreements, Dz. U. no. 79, item 891.

Szafarz, R. 1997) 'Kultura prawna prawa europejskiego na tle traktatów Rady Europy'. Studia Prawnicze, 1: 8.

Waltoś, S. 1996. Proces karny. Zarys sytemu, Wyd. 3. Warszawa: Wydawnictwa Prawnicze PWN.

Watts, A. 1996. Oppenheim's International Law. 1. London-New York: Longman.

Wędrychowska, E.L. and Wędrychowski, M.P. 1997. 'Pojęcie „niezawisłość sędziowska" w polskim procesie karnym jako element zasady uczciwego procesu'. Studia Iuridica, 33: 247.

Wędrychowski, M.P. 1991. "Prawo do „uczciwej rozprawy” w Europejskiej Konwencji Praw Człowieka'. Przeglad Sadowy, 2: 62.

Wiliński, P. 2003. Świadek incognito w polskim procesie karnym. Kraków: Wyd. Zakamycze.

Wróbel, A. 1991. 'Zarys koncepcji państwa prawnego w praktyce Rzecznika Praw Obywatelskich'. Biuletyn RPO. Materiaty, 40.

Zieliński, A. 1992. 'Postępowanie przed NSA w świetle „prawa do sprawiedliwego procesu sądowego" '. Państwo i Prawo, 7: 15. 